\title{
URGENSITAS MENDIRIKAN MADRASAH DI SAMPING MASJID (Studi Sejarah Pendidikan Islam Masa Pembaruan)
}

\author{
Khairuddin ${ }^{1}$, Muhammad Shaleh Assingkily² \\ ${ }^{1}$ Universitas Islam Negeri Sumatera Utara Medan \\ ${ }^{2}$ STIT Al-Ittihadiyah Labuhanbatu Utara
}

*Korespodensi: khairuddin@uinsu.ac.id

\begin{abstract}
ABSTRACK
Madrasas are the first formal educational institutions in the history of Islamic education. The madrasa institution that was first established by Nizhamiyah al-Mulk, is identical to its location next to the mosque. This shows how the syiar of Islam in the renewal era is "decorated" with nuances of knowledge (intellectual). This paper aims to analyze the urgency of establishing a madrasa next to the mosque. The focus of the discussion is how the urgency of establishing a madrasa next to a mosque and its impact on the advancement of Islamic education today. This research uses a qualitative approach with the library research method, then the validity of the data is tested based on literature (reference) which comes from scientific works, including final assignments (thesis, thesis, dissertation), scientific articles and proceedings (national-international). Through this research, it was found that the establishment of a madrasa next to a mosque is very urgent. This is based on the function of mosques in Islamic syiar, apart from being a place of prayer, mosques also function as centers of education, even the combination of mosques and madrasas is a symbol of dynamic Islamic education renewal and provides the widest possible ijtihad space for zanni Islamic studies. Thus, establishing a madrasa next to the mosque is a comprehensive symbol of Islam in the field of education.
\end{abstract}

Keyword: Renewal Period, Madrasah, Mosque, History of Islamic education.

\begin{abstract}
ABSTRAK
Madrasah merupakan lembaga pendidikan formal pertama dalam sejarah pendidikan Islam. lembaga madrasah yang didirikan pertama kali oleh Nizhamiyah al-Mulk, identik dengan lokasinya yang berada di samping masjid. Ini menunjukkan betapa syiar Islam di masa pembaruan "dihiasi" dengan nuansa ilmu (intelektual). Tulisan ini bertujuan menganalisa urgensitas mendirikan madrasah di samping masjid. Adapun fokus pembahasan yaitu bagaimana urgensitas mendirikan madrasah di samping masjid serta dampaknya bagi kemajuan pendidikan Islam di masa kini. Penelitian ini menggunakan pendekatan kualitatif dengan metode studi kepustakaan (library research), selanjutnya keabsahan data diuji berdasarkan literatur (referensi) yang bersumber dari karya ilmiah, meliputi tugas akhir (skripsi, tesis, disertasi), artikel ilmiah dan prosiding (nasional-internasional). Melalui penelitian ini, ditemukan hasil bahwa pendirian madrasah di samping masjid sangat urgen. Hal ini didasari dengan fungsi masjid dalam syiar Islam, selain sebagai tempat ibadah salat, masjid juga berfungsi sebagai pusat pendidikan, bahkan kombinasi masjid dan madrasah adalah simbol pembaruan pendidikan Islam yang dinamis dan memberi ruang ijtihad seluasnya terhadap kajian Islam yang bersifat zanni. Dengan demikian, mendirikan madrasah di samping masjid merupakan syiar Islam secara komprehensif di bidang pendidikan.
\end{abstract}

Kata Kunci: Masa Pembaruan, Madrasah, Masjid, Sejarah pendidikan Islam. 


\section{A. PENDAHULUAN}

Madrasah merupakan sekolah berbasis atau bercirikan Islam (Nurriqi, 2021; Mulyadi, 2018). Madrasah di Indonesia meliputi jenjang pendidikan dasar (MI setara dengan SD sederajat/MTs setara dengan SLTP sederajat), pendidikan menengah (MA setara dengan SLTA sederajat) dan pendidikan kejuruan (Madrasah Aliyah Kejuruan) (Alawiyah, 2014). Sumbangsih madrasah bagi kemajuan pendidikan Islam terhitung sejak awal didirikan secara formal di Indonesia (Nurhayati, 2013; Sudarsono, 2018). Dalam konteks ini, secara historis serbaserbi pendidikan Islam di Indonesia dan dalam catatan sejarah pendidikan Islam, tidak terlepas dari adanya madrasah (Syarifuddin, 2017).

Menurut Pratama (2019), madrasah merupakan tempat umat Islam mempelajari ilmu agama dan ilmu umum secara bersamaan sesuai dengan kurikulum pendidikan nasional. Senada dengan ini, Styaningsih (2016) menyebutkan bahwa awal mula pendirian madrasah di Indonesia serupa dengan pendirian madrasah pada masa pembaruan pendidikan Islam, yaitu berdekatan atau berada di samping masjid. Mencermati pendapat tersebut, dipahami bahwa terdapat hubungan erat antara masjid dan madrasah bagi pendidikan Islam (Wekke, et.al., 2019).
Berbeda halnya dengan pendapat sebelumnya, Basri menginformasikan bahwa pendirian madrasah sejak awal tahun 2000-an, tidak lagi identik berada di samping masjid. Begitupun, Maghrifal menambahkan bahwa kini penyelenggara pendidikan Islam di madrasah mulai berduyun membangun musola sebagai tempat pelaksanaan program madrasah, seperti salat Dhuha berjamaah, atau tempat kegiatan ke-Islaman.

Penyediaan fasilitas musola di madrasah, tidaklah mengambil peran signifikan bagi proses pendidikan di madrasah (Salim, 2015). Hal ini secara lugas dikritik oleh Natsir, et.al., (2020), bahwa musola yang dibangun oleh pihak madrasah berbeda dengan tujuan pendirian madrasah yang berada di samping masjid ketika masa pembaruan pendidikan Islam. Lebih lanjut, Daulay \& Pasa, (2013) menambahkan bahwa tujuan madrasah dan masjid berdampingan pada masa pembaruan pendidikan Islam adalah sebagai pusat pendidikan, sedangkan tujuan musola dibangun di komplek madrasah adalah sebagai pusat ibadah. Dalam konteks ini, dibutuhkan analisa lebih lanjut terkait hubungan pendirian keduanya sehingga berdampingan.

Sejatinya, penelitian tentang masjid dan madrasah secara terpisah, telah banyak diteliti oleh peneliti terdahulu. Di 
antaranya membahas konsep masjid yang ramah anak (Pakpahan, 2018; Atmaja \& Yusuf, 2021; Hasyim, 2018), madrasah ramah anak (Sholeh \& Humaidi, 2016; Sukma, et.al., 2019; Rahmawati, 2019), masjid sebagai sarana ibadah dan pendidikan Islam (Purwaningrum, 2021), masjid sebagai pusat kegiatan pendidikan Islam (Khairuni \& Widyanto, 2018; Mulyono, 2017; Amalia, 2019; Ahmad, 2010; Wage, 2018; Darodjat \& Wahyudhiana, 2014), eksistensi masjid dalam pengembangan pendidikan Islam (Rumondor \& Manese, 2020), pendidikan berbasis masjid (Tamrin, 2018; Husein, 2015; Mohamad, 2020; Muttaqin \& Faishol, 2018), peran masjid dalam peningkatan kualitas pendidikan Islam (Silfia, 2013), sistem pendidikan Islam di madrasah (Siren, et.al., 2014), dan perkembangan madrasah hingga di Indonesia (Drajat, 2018).

Mencermati literature review dan uraian di atas, dipahami bahwa terdapat "ruang kosong" penelitian tentang urgensitas pendirian masjid dan madrasah yang berdekatan. Untuk itu dibutuhkan kajian lebih lanjut tentang bagaimana awal pendirian madrasah serta pengembangannya pada masa pembaruan, yang berada di samping masjid, berbeda dengan konteks musola di dalam komplek madrasah era sekarang. Dengan demikian, dibutuhkan penelitian lebih mendalam tentang urgensitas pendirian keduanya secara berdampingan, yang terangkum dalam judul, "Urgensitas Pendirian Madrasah di Samping Masjid (Studi Sejarah Pendidikan Islam Masa Pembaruan)". Melalui penelitian ini, diharapkan masjid dan madrasah dapat berkolaborasi sebagai pusat ibadah dan pusat pendidikan Islam, sehingga terlahir alumni madrasah yang mampu menjadi para ilmuan Muslim yang mumpuni dan berkarakter.

\section{B. TINJAUAN PUSTAKA}

\section{Madrasah Sebagai Lembaga Pendidikan Islam}

Madrasah berasal dari bahasa Arab, akar katanya darasa, yang berarti "membaca atau belajar", sedang madrasah adalah isim makan dari darasa, yang artinya "tempat belajar" (Syahid, 2018). Secara terminologi, madrasah merupakan lembaga pendidikan Islam yang ada sejak masa klasik, setelah masjid dan kuttab (Daulay \& Pasa, 2013). Keberadaan madrasah semakin menguat setelah Nizhamiyah al-Mulk melebarkan pendirian madrasah ke berbagai penjuru negeri (Isbir, 2017; Ahmad, 2015; Muspiroh, 2017; Mutaqin, 2020). Di Indonesia sendiri, banyak madrasah yang turut memberi sumbangsih bagi kemajuan pendidikan Islam di Indonesia, seperti Madrasah Adabiyah, Madrasah Diniyah, 
Madrasah Mambaul 'Ulum dan Madrasah Nahdlatul Wathan (Drajat, 2018).

Secara historis, Daulay \& Pasa (2013) menyebutkan madrasah adalah lembaga pendidikan Islam yang muncul setelah masjid. Hal ini didasari kebutuhan dan peningkatan jumlah pelajar. Untuk itu, peran madrasah sejak awal (masa klasik) hingga kini memberikan sumbangsih atau kontribusi yang besar bagi kemajuan pendidikan Islam.

Secara formal, madrasah mulai melembaga di bawah naungan Departemen Agama RI sejak 3 Januari 1946, dan diakui sebagai lembaga penyelenggara pendidikan sejak tahun 1950 yang mengacu pada UU Nomor 4 tahun 1950 tentang Dasar-Dasar Pendidikan dan Pengajaran Pasal 10. Pengakuan ini diberikan kepada madrasah, dengan catatan memberikan pelajaran agama sebagai materi ajar pokok minimal 6 (enam) jam selama seminggu. Inilah yang mendasari istilah madrasah sebagai sekolah bercirikan Islam.

Menurut Ramayulis (2011), kehadiran awal madrasah dipandang sebagai lembaga yang hanya "sektarian" mengajarkan ilmu agama Islam, sedangkan ilmu atau materi umum yang diajarkan tidak sebanding dengan di sekolah. Atas dasar inilah, Mahmud Yunus (Kasi Islam Departemen Agama RI) mengusulkan kurikulum madrasah dibagi menjadi 3 bagian, 1/3 materi agama Islam, sedangkan 2/3 lainnya disesuaikan dengan materi umum di sekolah.

Berdasarkan uraian di atas, dipahami bahwa madrasah merupakan lembaga pendidikan Islam yang memiliki kontribusi besar bagi penyebaran dan kemajuan pendidikan Islam di dunia. Di Indonesia, madrasah adalah lembaga pendidikan formal yang setara dengan sekolah pada setiap jenjang, mulai dari pendidikan dasar hingga pendidikan tinggi. Lebih dari itu, kontribusi madrasah sangat erat dengan sejarah dan perkembangan pendidikan Islam di Indonesia.

\section{Masjid Sebagai Lembaga Pendidikan Islam}

Masjid berasal dari bahasa Arab, yaitu sajada yang berarti "tempat sujud" (Prayitno, 2010). Secara terminologi, masjid diartikan sebagai tempat peribadatan orang Muslim. Peran masjid sebagai tempat ibadah menjadi alasan mendasar bagi umat untuk memuliakan bangunan masjid (Kurniawan, 2014). Sebab, berbagai aktivitas ibadah dan keislaman dilaksanakan di dalam masjid.

Menurut Daulay \& Pasa (2013), masjid sejak masa Nabi saw. memiliki fungsi ganda, yaitu sebagai tempat ibadah (salat dan lainnya) dan tempat kegiatan sosial kemasyarakatan (musyawarah dan lainnya). Lebih lanjut, Khikmawati (2020) 
menerangkan bahwa masjid adalah tempat ibadah umat Islam, begitupun ada fungsi lain masjid yang tak kalah penting sebagai pusat kegiatan pendidikan umat Islam sejak zaman klasik. Putra \& Rumondor (2019) menambahkan, eksistensi masjid sejak zaman nabi saw. sakral (dimuliakan) dan syiar Islam, termasuk sebagai salah satu lembaga pendidikan Islam terkemuka.

Secara kuantitas, masjid sebagai salah satu lembaga pendidikan Islam terhitung pesat dalam sejarah pendidikan Islam. Shalaby (1976) menginformasikan bahwa jumlah masjid saat kejayaan pendidikan Islam sangat banyak dan tersebar di berbagai penjuru, Kota Baghdad terdapat 30.000 masjid, Kota Iskandaria terdapat 12.000 masjid, dan Damaskus terdapat 500 masjid. Secara kualitas, Asari (2007) menjelaskan bahwa terdapat tenaga pengajar khusus diangkat oleh khalifah untuk mengajar di masjidmasjid. Ini menunjukkan betapa peran dan fungsi masjid memberi kontribusi besar bagi kemajuan pendidikan Islam. Lebih lanjut, Daulay \& Pasa (2013) mendeskripsikan bahwa terdapat penginapan atau asrama pada beberapa masjid. Hal ini ditujukan sebagai fasilitas khusus bagi musafir atau pelajar dari luar daerah. Masjid dengan fasilitas penginapan tersebut disebut dengan istilah masjid khan (sebab, khan sendiri berarti penginapan).
Revitalisasi fungsi dan peran masjid bagi kemajuan pendidikan Islam sangat penting (Rifa'i, 2016). Hal ini didasari oleh aspek historisitas masjid yang sejak awal berfungsi sebagai salah satu lembaga pendidikan Islam dan masjid merupakan tempat pusat kegiatan pendidikan Islam. Bahkan, pendirian madrasah, kuttab, perpustakaan dan lembaga pendidikan Islam lainnya, berpusat sejak awal di masjid. Sehingga, madrasah-madrasah yang ada sejak awal kemajuan pendidikan Islam berdiri tegak berdampingan dengan masjid.

\section{Masa Pembaruan Pendidikan Islam}

Istilah baru atau pembaruan, kerap kali dikaitkan dengan terma "tajdid dan modernitas". Menurut Daulay \& Pasa (2013), pembaruan sederhananya dimaknai sebagai perubahan pemikiran, sikap, perilaku yang didasarkan kepada perkembangan dan kemajuan zaman. Senada dengan ini, Nasution (2018) menyebutkan bahwa pembaruan dalam pendidikan Islam identik dengan kemajuan sains dan teknologi. Lebih lanjut, Nasution (1996) menyebutkan bahwa segala pembaruan dan suasana baru yang muncul darinya, bermuara dari kemajuan sains dan teknologi modern.

Hakikat pembaruan ialah pemikiran. Perubahan pada pemikiran mengantarkan insan secara individu 
ataupun kelompok untuk berubah, baik sikap maupun perilakunya. Hal ini sesuai dengan fitrah manusia sebagai makhluk inovatif. Begitupun, Islam membatasi pembaruan dalam aspek zanni (ajaran yang memerlukan interpretasi) saja, sedangkan wilayah qath' $i$ tidak.

Pembaruan pendidikan Islam adalah "buah" inovatif dari zaman sebelumnya, yaitu zaman kemajuan (650 M-1000 M) dan kemunduran (1250 M1800 M). Sebagai langkah komparatif, umat Islam menganalisa alasan utama kemundurannya. Dalam konteks ini, Rahman (2000) menjelaskan bahwa kemacetan dan tertutupnya pintu ijtihad (interpretasi) terhadap ajaran Islam yang zanni, menjadi penyebab utama mundurnya peradaban Islam. Ini menunjukkan bahwa dinamika berpikir adalah keniscayaan bagi manusia dalam setiap zaman/masa. Karena, tidak boleh tidak, umat Islam harus terus mengasah intelektualitas berpikirnya sebagai implementasi fitrah inovasi manusia.

Kesadaran umat Islam pasca zaman kemunduran, menimbulkan gerakangerakan pembaruan di seluruh penjuru negeri, mulai dari Mesir yang diprakarsai oleh Muhammad Ali Pasha, pembaruan pendidikan di Turki diprakarsai oleh Sultan Mahmud II, pembaruan pendidikan di India diprakarsai oleh Sayyid Ahmad Khan. Selanjutnya, pengaruh pembaruan pemikiran Islam yang muncul dari berbagai negara tersebut, menjadi aspek yang melatarbelakangi pembaruan pendidikan di Indonesia, terbukti dengan didirikannya Sekolah Adabiyah yang diprakarsai oleh Syaikh Abdullah Ahmad pada tahun 1909 di Padang Sumatera Barat.

Secara historis, Daulay \& Pasa (2013) menyebutkan bahwa pembaruan pendidikan Islam identik dengan pendirian lembaga pendidikan. Kesemuaannya diawali dari pendirian masjid sebagai pusat ibadah dan kegiatan pendidikan. Sebut saja di Aceh, meunasah mula-mula dijadikan sebagai tempat pusat kegiatan pendidikan, lantas berdiri dayah dan madrasah. Begitu juga di Sumatera Barat, surau merupakan lembaga pendidikan awal bagi masyarakat setempat, selanjutnya berdiri madrasah. Ini menunjukkan bahwa pendirian lembaga pendidikan Islam sejak zaman pembaruan tidak terlepas diawali oleh tempat-tempat ibadah.

Berdasarkan uraian di atas, dipahami bahwa sejak zaman pembaruan, madrasah sangat identik dengan posisinya yang berdampingan dengan masjid, surau, atau meunasah. Hal ini dimaksudkan sebagai upaya pengembangan lembaga pendidikan Islam, guna menyahuti kebutuhan masyarakat yang tinggi akan belajar pendidikan Islam, serta memfasilitasi jumlah peserta didik yang kian 
bertambah pesat. Dengan demikian, tampaklah bahwa urgen pendirian madrasah berdampingan dengan masjid.

\section{METODE}

Penelitian ini menggunakan pendekatan kualitatif dengan metode studi kepustakaan (library research). Objek kajian penelitian ini adalah buku, tugas akhir, artikel ilmiah, dan sumber literasi ilmiah terkait (1) urgensitas pendirian madrasah di samping masjid di masa pembaruan dan (2) dampaknya terhadap kemajuan pendidikan Islam di era saat ini. Analisis data dilakukan secara komprehensif dengan menganalisa urgensitas dan dampak pendirian madrasah di samping masjid. Dengan demikian, penelitian ini dapat menemukan sejarah pendirian madrasah, korelasi pendirian madrasah di samping masjid, dan dampaknya terhadap pendidikan Islam di era sekarang. Oleh karena itu, pengecekan data dalam penelitian ini dapat dilakukan menggunakan bahan referensi (Prastowo, 2014; Assingkily, 2021).

\section{HASIL PEMBAHASAN}

\section{Sejarah Madrasah Sebagai Lembaga}

\section{Pendidikan Islam}

Madrasah merupakan lembaga pendidikan Islam yang muncul setelah masjid dan kuttab. Kehadiran madrasah sejak tahun ke-4 Hijriah ialah sebagai jawaban atas tuntutan kebutuhan zaman (Zuhdi, 2012). Menurut Daulay \& Pasa, (2013), faktor utama yang mendorong berdirinya madrasah ialah disebabkan jumlah pelajar yang meningkat secara signifikan, sehingga masjid tidak mungkin lagi menampung untuk tempat belajar.

Senada dengan di atas, Nizah (2016) menginformasikan bahwa pembelajaran yang dilaksanakan dengan sistem halaqah pada saat itu, menjadikan keadaan belajar tidak kondusif, menimbulkan suara bising, bahkan dapat mengganggu kekhusyukan dalam beribadah di masjid. Hal inilah yang mendasari Nizamul Mulk (1018-1092) mendirikan Madrasah Nizamiyah pada abad ke-5 Hijriah dan tersebar ke berbagai negeri (Daulay \& Pasa, 2013). Rahim (2014) menambahkan bahwa orientasi pembelajaran (kurikulum) madrasah ini (pembaruan pendidikan Islam) yaitu membaca, menghafal dan mampu menuliskan al-Qur'an, selanjutnya memahami sastra Arab, sejarah kenabian (Muhammad saw.), berhitung dan pemahaman mazhab fikih serta teoloi 'Asyariyah.

Setelah itu, mulailah bermunculan madrasah lainnya dalam sejarah Islam, seperti Madrasah Al-Mustanshiriyyah yang didirikan oleh Khalifah alMuntanshir pada abad ke-13 Hijriah (Muqoyyidin, 2013). Inilah cikal-bakal 
penyebaran pendirian madrasah dalam dunia pendidikan Islam, sehingga di India muncul Madrasah Deoband yang sangat terkenal melahirkan para ulama India (Begum \& Kabir, 2012; Ali \& Zin, 1999; Reetz, 2005). Indonesia sendiri juga muncul berbagai madrasah yang sangat terkenal, di antaranya Madrasah Nahdlatul Wathan (Hadisaputra \& Yussuf, 2020), Madrasah Mambaul 'Ulum (Mulyanto, et.al., 2019), Madrasah Adabiyah (PadangSumatera Barat) (Susilawati, 2008), Madrasah Diniyah (Sumatera Barat) (Mukhlis, 2017), hingga kini madrasah sudah setara dan berstatus sama dengan sekolah-sekolah di Indonesia yang bercirikan agama Islam (Wardi, et.al., 2019). Kesemuaan madrasah tersebut, berdiri berdampingan dengan masjid (Harahap, 2018; Akhiruddin, 2015).

Berdasarkan uraian di atas, dipahami bahwa madrasah merupakan lembaga pendidikan Islam sejak awal setelah masjid dan kuttab. Pendirian madrasah berada berdampingan dengan masjid. Ini membuktikan bahwa sejak awal hingga masa pembaruan pendidikan Islam, madrasah memiliki peran penting bagi kemajuan pendidikan Islam. lebih dari itu, ini juga didasari oleh posisi madrasah yang berdampingan dengan masjid, sehingga pusat ibadah dan pusat kegiatan pendidikan Islam berposisi sentral dalam 1 (satu) komplek.

\section{Madrasah dan Masjid di Masa Pembaruan Pendidikan Islam}

Madrasah merupakan lembaga pendidikan Islam yang muncul setelah masjid (Affandi, 2020). Hal ini didasarkan pada kapasitas dan kondusivitas pembelajaran di masjid yang tidak lagi nyaman bagi orang beribadah, dengan penambahan jumlah pelajar yang signifikan. Padahal, terdapat 42.500 masjid yang tersebar di Damaskus, Baghdad, dan Iskandaria (Shalaby, 1976). Selain menyahuti kebutuhan masyarakat dan jumlah pelajar yang meningkat, kehadiran madrasah sebagai lembaga pendidikan merupakan bentuk pengembangan dari masjid dengan fungsi gandanya sebagai tempat ibadah dan pusat kegiatan pendidikan Islam.

Madrasah merupakan lembaga pendidikan Islam yang memberi sumbangsih (kontribusi) besar bagi kemajuan pendidikan Islam di Indonesia (Ahid, 2009). Keberadaan madrasah di tengah-tengah masyarakat, seolah mampu menjawab kebutuhan masyarakat Indonesia (Susilawati, 2008). Begitupun, eksistensi madrasah mulai tergerus dengan hadirnya lembaga pendidikan Islam lainnya, misalnya sekolah Islam terpadu dan tantangan modernitas di abad 21 (Kurniawan, 2019). 
Kehadiran madrasah sebagai lembaga pendidikan tidak terpisah dengan masjid. Hal ini terbukti dengan berbagai pembaruan pendidikan Islam di dunia yang berawal dari masjid (lembaga pendidikan yang sejenis). Di Indonesia, terbukti madrasah yang didirikan pertama kali di Padang-Sumatera Barat, juga diawali dengan pembelajaran di Surau, serta posisi madrasah berdampingan dengan surau (Nasir, 2017). Ini menunjukkan bahwa masjid dan madrasah berdampingan sejak awal berdirinya sebagai lembaga pendidikan Islam.

Posisi yang berdampingan antara masjid dan madrasah, bukanlah sekadar hubungan kedekatan antardua bangunan. Lebih dari itu, mengindikasikan pentingnya kombinasi antara pusat ibadah dan pusat kegiatan pendidikan (Wekke, et.al., 2019). Sebab, peserta didik tidak hanya berpacu dalam mengasah IQ dan EQ semata, melainkan memperoleh penguatan SQ selama proses pendidikan (Sutarman \& Tjahjono, 2019). Penguatan intelektual dan ijtihad terhadap ajaran Islam (wilayah zanni), difokuskan dalam satu latar lembaga pendidikan.

Masjid dan madrasah urgen berada berdampingan, disebabkan keseimbangan yang dihadirkan oleh keduanya antara acquired knowledge dan perennial knowledge (Surajudeen \& Mat, 2013; Hardaker \& Sabki, 2018; Anee, et.al.,
2020). Tidak hanya terfokus pada materi umum, peserta didik juga dididik materimateri keagamaan yang mengantarkan pada tujuan pendidikan Islam, membentuk insan paripurna (Harahap \& Siregar, 2017), insan sejati dan/atau insan kamil (Deswita, 2010).

Berdasarkan uraian di atas, dipahami bahwa madrasah dan masjid sejak masa periode klasik berdiri secara berdampingan. Sebagai lembaga yang hadir sejak tahun $4 \mathrm{H}$, madrasah merupakan lembaga tempat pusat kegiatan pendidikan Islam. Begitupun, peran madrasah bukanlah sebagai pengganti masjid, melainkan lembaga pengembangan dari masjid yang berkombinasi dengan kegiatan spiritual dan ibadah di masjid.

\section{Implikasi Pendirian Madrasah di Samping Masjid Bagi Kemajuan Pendidikan Islam Masa Kini}

Abad keduapuluh merupakan era kebangkitan bagi pendidikan Islam dunia, pasca masa pembaruan (Manti, et.al., 2016). Hal ini seiring dengan merdekanya negara-negara mayoritas Muslim di abad $\mathrm{XX}$, sekaligus menandakan kemandirian bangsa dalam segala aspek kehidupan tanpa campur tangan, apalagi intimidasi pihak lain (Embong, 2020). Kemandirian bangsa-bangsa mayoritas Muslim ini, disahuti secara positif dengan pelaksanaan konferensi Islam se-Dunia tentang 
pendidikan (Daulay \& Pasa, 2013), pembentukan Organisasi Konferensi Islam (OKI) (Azhar, 2002), dan kebangkitan universitas Islam di dunia (Hanifah, 2018; Jalaluddin, 2014).

Berbagai prestasi, capaian dan kemajuan dunia pendidikan Islam tidak terlepas dari sejarah madrasah sebagai lembaga pendidikan terkemuka, yang menjadi cikal-bakal pendirian Universitas Nizhamiyah (Rohana, 2020; Muthoharoh, 2018). Menurut Asari (2007), madrasah dalam catatan sejarah memberi kontribusi besar bagi kemajuan pendidikan Islam masa kini. Lebih lanjut, Ismawati (2015) menambahkan bahwa peran serta madrasah sejak periode klasik selalu disertai dengan pendampingan masjid di sampingnya. Ini menunjukkan bahwa kemajuan dan kejayaan pendidikan Islam di "mata dunia" tidak terlepas dari integrasi antara acquired knowledge dan perennial knowledge.

Berdirinya madrasah di dekat masjid, menurut Rafiq (2017) adalah simbolis dari integrasi keilmuan. Syamsul (2020) menambahkan, bahwa Islam akan jaya dari seluruh aspek bila lembaga pendidikannya memberi penguatan spiritual kepada peserta didik, serta memberi ruang ijtihad bagi ajaran Islam yang bersifat zanni (membutuhkan interpretasi). Dengan demikian, dinamika berpikir dan kehidupan dinamis diperoleh sekaligus oleh umat Islam.

Secara kontekstual, peran masjid sejak awal pendirian madrasah sangatlah besar. Sebab, pusat ibadah dan pusat kegiatan pendidikan Islam terkombinasi dalam satu komplek. Hal inilah yang menguatkan masyarakat Muslim dalam meraih kejayaan. Kafrawi (2019) mengistilahkannya sebagai kombinasi dua pusat kegiatan fundamental umat Islam dalam menyiarkan Islam.

Keberadaan masjid di sebelah (bagian samping) madrasah, kini sudah tergerus dengan perubahan zaman. Lembaga madrasah di Indonesia fokus terhadap berbagai inovasi, namun meninggalkan esensi dan eksistensi keberadaan masjid di sampingnya (Zaimuddin, 2018; Sassi, 2019; Hasanuddin, 2014). Padahal, masjid bukanlah sekadar bangunan yang berada di samping madrasah, lebih dari itu keberadaan masjid memberikan motivasi, penguatan dan berbagai aktivitas pendidikan bagi umat Islam. Meskipun begitu, kini berbagai lembaga madrasah sudah mulai mendirikan musola sebagai pengganti masjid di era klasik dan pembaruan pendidikan Islam. Hanya saja, tujuan pendirian musola masih terbatas pada tempat ibadah semata, berbeda dengan "gaung" masjid yang berdiri di samping madrasah pada era klasik, 
kemajuan, pembaruan dan kebangkitan pendidikan Islam di dunia.

Berdasarkan uraian di atas, dipahami bahwa keberadaan masjid di samping madrasah sangatlah urgen. Hal ini didasari dengan peranan masjid yang menjadi simbol dan kekuatan syiar Islam, termasuk bidang pendidikan. Berbagai aspek ibadah dan pendidikan yang terpusat di masjid dan madrasah secara kombinatif, akan menghadirkan nuansa dan suasana nyaman bagi proses pembelajaran. Di samping itu, degradasi moral sebagai permasalahan yang mengakar dalam dunia pendidikan saat ini, dapat diminimalisir bahkan dihindari melalui penerapan pembelajaran yang seimbang di masjid dan madrasah.

\section{E. KESIMPULAN}

Berdasarkan hasil dan pembahasan penelitian, diperoleh simpulan bahwa pendirian madrasah di samping masjid adalah hal urgen dalam dunia pendidikan Islam. Hal ini didasari fungsi keduanya dalam sejarah pendidikan Islam sebagai pusat kegiatan dan lembaga pendidikan. Di samping itu, peran masjid di samping masjid tidak hanya sekadar simbolis bangunan tempat ibadah umat Islam. Lebih dari itu, keberadaan keduanya berdampingan adalah bagian syiar Islam, penguatan akhlak, dan bukti integrasi keilmuan. Eksistensi dan esensi keduanya di bidang pendidikan Islam tidak terlepas dari pengalaman masa lalu, tepatnya pasca masa kemunduran Islam, yaitu masa pembaruan pendidikan Islam.

\section{DAFTAR PUSTAKA}

Affandi, M. Arief. (2020). "Kuttab dan Institusi Pendidikan Islam PraLahirnya Sistem Madrasah" Taujih: Jurnal Pendidikan Islam, 13(2). http://ejurnal.stitqi.ac.id/index.php/taujih/art icle/view/187.

Ahid, Nur. (2009). "Madrasah Sebagai Institusi Pendidikan: Sejarah Pertumbuhan dan Perkembangannya" Tribakti: Jurnal Pemikiran Keislaman, 20(1). https://ejournal.iai-

tribakti.ac.id/index.php/tribakti/articl e/view/91.

Ahmad, Entus Riyadhy. (2015). "Madrasah Nizhamiyah Pengaruhnya Terhadap Perkembangan Pendidikan Islam dan Aktivitas Ortodok Sunni" Tarbiya: Jurnal Ilmu Pendidikan Islam, $\quad 1(1)$. https://journal.uinsgd.ac.id/index.php /jurnal-tarbiya/article/view/140.

Ahmad, Mohd Yusuf. (2010). "Pengajaran dan Pembelajaran Pendidikan Islam di Masjid" Seminar Pengajaran Pembelajaran Berasaskan Masjid 2010, 18-19 Februari, Masjid Negeri Sultan Salahuddin Abdul Aziz, Shah Alam.

http://library.oum.edu.my/repository/ 550/.

Akhiruddin, KM. (2015). "Lembaga Pendidikan Islam di Nusantara" Tarbiya: Jurnal Ilmu Pendidikan Islam, $1(1)$. https://journal.uinsgd.ac.id/index.php /jurnal-tarbiya/article/view/143.

Alawiyah, Faridah. (2014). "Pendidikan Madrasah di Indonesia" Aspirasi: Jurnal Masalah-masalah Sosial, 5(1).

http://jurnal.dpr.go.id/index.php/aspir asi/article/view/449. 
Ali, Aizah Hj. \& Mat Zin. (1999). "Islamic Institution of Education in British India: A Study on Deoband Madrasah" Jurnal Ushuluddin, 9. http://jice.um.edu.my/index.php/JUD /article/view/3766.

Amalia, Rizky. (2019). "Pemanfaatan Masjid Sebagai Pusat Pendidikan Islam Nonformal (Studi Kasus di Masjid Al-Jami' Plupuh Kabupaten Sragen Tahun 2019)" Skripsi. IAIN Salatiga. http://erepository.perpus.iainsalatiga.ac.id/5 538/.

Anee, Umme Salma, et.al. (2020). "Knowledge, Attitude and Practice on Female Hygiene Management Among Madrasa Girls in Dhaka, Bangladesh" Asian Journal of Multidisciplinary Studies, 3(1). https://asianjournal.org/online/index. php/ajms/article/view/231.

Asari, Hasan. (2007). Menyingkap Zaman Keemasan Islam: Kajian atas Lembaga-lembaga Pendidikan. Bandung: Mizan, Citapustaka Media. http://scholar.google.com/scholar?clu $\underline{\text { ster }=13994691716094774962 \& \mathrm{hl}=\mathrm{en}}$ \&oi=scholarr.

Assingkily, Muhammad Shaleh. (2021). Penelitian Tindakan Kelas. Medan: Pusdikra Mitra Publishing.

Atmaja, Fajar Fandi \& Syaifulloh Yusuf. (2021). "Model Pendampingan Manajemen Masjid Ramah Anak dan Aman Covid-19 di Masjid AlMusthofa Dusun Jaten, Sendangadi, Mlati, Sleman" Yumary: Jurnal Pengabdian kepada Masyarakat, 1(3).

https://penerbitgoodwood.com/index. php/jpm/article/view/222.

Azhar, Muhammad. (2002). "Mengenal dari Dekat: Organisasi Konferensi Islam (OKI)" Tarjih: Jurnal Tarjih dan Pengembangan Pemikiran Islam, $3(1)$. https://www.jurnal.tarjih.or.id/index. php/tarjih/article/view/3106.
Basri, Hasan. (2017). "Disorientasi Pendidikan Madrasah di Indonesia" Potensia: Jurnal Kependidikan Islam, 3(1). http://dx.doi.org/10.24014/potensia.v $\underline{3 i 1.3470 .}$.

Begum, Momotaj \& Humayun Kabir. (2012). "Reflections on the Deobandi Reformist Agenda in a Female Quomi Madrasah in Bangladesh" South Asia: Journal of South Asian Studies, $35(2)$. https://doi.org/10.1080/00856401.20 12.659650.

Darodjat \& Wahyudhiana. (2014). "Memfungsikan Masjid Sebagai Pusat Pendidikan untuk Membentuk Peradaban Islam" Islamidina: Jurnal Pemikiran Islam, 13(2). http://jurnalnasional.ump.ac.id/index. php/ISLAMADINA/article/view/167 5 .

Daulay, Haidar Putra \& Nurgaya Pasa. (2013). Pendidikan Islam dalam Lintasan Sejarah (Kajian dari Zaman Pertumbuhan Sampai Kebangkitan). Jakarta: Kencana.

Deswita. (2010). "Pendidikan Berbasis Kecerdasan Ruhaniah (Membentuk Insan Paripurna/Insan al-Kamil)" Ta'dib, 13(2). http://ojs.iainbatusangkar.ac.id/ojs/in dex.php/takdib/article/viewFile/190/ 189.

Drajat, M. (2018). "Sejarah Madrasah di Indonesia" Al-Afkar: Journal for Islamic Studies. http://alafkar.com/index.php/Afkar_Journal/a rticle/view/17.

Embong, Rahimah. (2020). "Perkembangan Pendidikan Islam di Nusantara: Malaysia dan Indonesia" Tamaddun: Jurnal Pendidikan dan Pemikiran Keagamaan, 21(1). http://dx.doi.org/10.30587/tamaddun. v21i1.1385.

Hadisaputra, Prosmala \& Ahmad bin Yussuf. (2020). "Karakteristik Guru dalam Tradisi Pendidikan Nahdlatul Wathan, Lombok" At-Tafkir, 13(1). 
https://doi.org/10.32505/at.v13i1.144 1.

Hanifah, Umi. (2018). "Islamisasi Ilmu Pengetahuan Kontemporer (Konsep Integrasi Keilmuan di UniversitasUniversitas Islam Indonesia)" Tadris: Jurnal Pendidikan Islam, 13(2).

http://ojs3.iainmadura.ac.id/index.ph $\mathrm{p} /$ tadris/article/view/1972.

Harahap, Musaddad \& Lina Mayasari Siregar. (2017). "Konsep Pendidikan Islam dalam Membentuk Manusia Paripurna" Al-Thariqah: Jurnal Pendidikan Agama Islam, 2(2). https://doi.org/10.25299/althariqah.2 017.vol2(2).1040.

Harahap, Arfiansyah. (2018). "Madrasah: From Early TIME to Nizhamiah (Sejarah Sosial dan Kelembagaan Pendidikan Islam)" Jurnal Progress, 6(1).

https://dx.doi.org/10.31942/pgrs.v6i1 .2204.

Hardaker, Glenn \& Aishah Ahmad Sabki. (2018). "A Spiritual Understanding of Islamic Education" Pedagogy in Islamic Education. https://doi.org/10.1108/978-1-78754531-120181005.

Hasanuddin. (2014). "Dominasi Peradaban Barat dalam Pendidikan Islam" $A l$ Hikmah: Journal for Religious Studies, 15(3). https://www.neliti.com/publications/ 30630/dominasi-peradaban-baratdalam-pendidikan-islam.

Hasyim, Wakhid. (2018). "Kajian Hadis Mengenai Masjid Ramah Perkembangan Anak" Jurnal Living Hadis, 3(2). http://ejournal.uinsuka.ac.id/ushuluddin/Living/article/ view/1697.

Husein, Saddam. (2015). "Peran Masjid dalam Pendidikan Islam Nonformal untuk Pembinaan Umat (Studi Kasus di Masjid Mardhatillah Gempol Ngadirejo Kartasura Sukoharjo)" Skripsi. Universitas Muhammadiyah
Surakarta.

http://eprints.ums.ac.id/34921/.

Isbir, Moh. (2017). "Studi tentang Madrasah Nizhamiyah" Tasyri": Jurnal Tarbiyah-Syari'ah Islamiyah, 24(1).

http://ejournal.kopertais4.or.id/pantur a/index.php/tasyri/article/view/3174.

Ismawati. (2015). "Peran Madrasah Nizhamiyah pada Masa Nizham AlMulk 1065-1072" Skripsi. Jakarta: Jurusan Sejarah dan Kebudayaan Islam, Fakultas Adab dan Humaniora, UIN Syarif Hidayatullah Jakarta.

https://repository.uinjkt.ac.id/dspace/ bitstream/123456789/29668/1/ISMA WATI\%20-\%20FAH\%20.

Jalaluddin. (2014). "Peran Universitas Islam Negeri (UIN) Menyongsong Kebangkitan Tradisi Keilmuan Islam" Jurnal Conciencia, 14(2). http://jurnal.radenfatah.ac.id/index.p $\mathrm{hp} /$ conciencia/article/view/93.

Kafrawi. (2019). "Pendidikan Islam dan Madrasah" Al-Liqo: Jurnal Pendidikan Islam, 4(1).

https://ejournal.staitbh.ac.id/index.php/alliqo/article/view/17.

Khairuni, Nisa \& Anton Widyanto. (2018). "Optimalisasi Fungsi Masjid Sebagai Sarana Pendidikan Islam dalam Menyelesaikan Krisis Spiritual Remaja di Banda Aceh" Dayah: Journal of Islamic Education, 1(1). https://www.jurnal.arraniry.ac.id/index.php/JIE/article/vie w/2482.

Khikmawati, Nurlaili. (2020). "Pemberdayaan Berbasis Religi: Melihat Fungsi Masjid Sebagai Ruang Religi, Edukasi dan Kultural di Masjid Darussa'adah, Kota Bandung" Islamic Management and Empowerment Journal, 2(2). https://www.ejournal.iainsalatiga.ac.id/index.php/i mej/article/view/5283. 
Kurniawan, S. (2014). "Masjid dalam Lintasan Sejarah Umat Islam" Journal of Islamic Studies, 4(2): 169184.

https://www.academia.edu/download 154388882/Masjid_dalam_Lintasan_

Sejarah_Umat_Islam.pdf.

Kurniawan, Syamsul. (2019). "Tantangan Abad 21 Bagi Madrasah di Indonesia” Intizar, 25(1). http://jurnal.radenfatah.ac.id/index.p hp/intizar/article/view/3242.

Maghrifal, Siti Amatul. (2019). "Profil Madrasah Unggul (Studi Deskriptif pada MIN 1 Temanggung Kabupaten Temanggung) Tahun Pelajaran 2018/2019” Skripsi. IAIN Salatiga. http://e-

repository.perpus.iainsalatiga.ac.id/5 512/.

Manti, Biltiser Bachtiar, et.al. (2016). "Konsep Pendidikan Modern Mahmud Yunus dan Kontribusinya Bagi Lembaga Pendidikan Islam di Indonesia" Ta'dibuna: Jurnal Pendidikan Islam, 5(2). http://ejournal.uika-

bogor.ac.id/index.php/TADIBUNA/a rticle/view/589.

Mohamad, Aminuddin. (2020). "Pendidikan Islam Berbasis Masjid Baitul Arqam Studi Kasus di Komplek Perumahan Griya Satria Indah II Sumampir" Tesis. IAIN Purwokerto.

http://repository.iainpurwokerto.ac.id 17571/.

Mukhlis, Abdul. (2017). "Sejarah Lembaga-lembaga Pendidikan Islam Nusantara (Surau, Meunasah, Pesantren dan Madrasah)" Al-Iman: Jurnal Keislaman dan Kemasyarakatan, $\quad 1(1)$. http://ejournal.kopertais4.or.id/madur a/index.php/aliman/article/view/3005

Mulyadi, Edi. (2018). "Strategi Pengembangan Budaya Religius di Madrasah" Jurnal Kependidikan, 6(1). https://doi.org/10.24090/jk.v6i1.1688

Mulyanto, et.al. (2019). "Modernisasi Madrasah Awal Abad XIX: Studi Analisis Madrasah Mambaul Ulum Surakarta (1904-1945)" Edukasi Islami: Jurnal Pendidikan Islam, $8(2)$.

http://jurnal.staialhidayahbogor.ac.id/ index.php/ei/article/view/537.

Mulyono. (2017). "Rekonstruksi Peran dan Fungsi Masjid Sebagai Pusat Kegiatan Pendidikan Islam" Muaddib: Jurnal Studi Kependidikan dan Keislaman, 7(1). http://dx.doi.org/10.24269/muaddib.v 7i01.555.

Muqoyyidin, Andik Wahyun. (2013). "Aktualisasi Pendidikan Islam di dalam Institusi-Institusi Madrasah Terkemuka Abad Klasik" Madrasah: Jurnal Pendidikan dan Pembelajaran Dasar, 6(1). http://ejournal.uinmalang.ac.id/index.php/madrasah/arti cle/view/3287.

Muspiroh, Novianti. (2017). "Madrasah Nizhamiyah: Sebuah Momentum dalam Sejarah Pendidikan Islam" Tamaddun: Jurnal Sejarah dan Kebudayaan Islam, 5(1). https://www.syekhnurjati.ac.id/jurnal /index.php/tamaddun/article/view/19 97.

Mutaqin, Jaenal. (2020). "Semangat Ilmuwan Muslim dalam Pengembangan Institusi Pendidikan Madrasah Nizhamiyah dan Ilmu Pengetahuan pada Masa Dinasti Abbasiyah" Tesis. Jakarta: Pendidikan Agama Islam, Fakultas Ilmu Tarbiyah dan Keguruan, UIN Syarif Hidayatullah Jakarta. https://repository.uinjkt.ac.id/dspace/ handle/123456789/53690.

Muthoharoh, Miftakhul. (2018). "Wajah Pendidikan Islam di Spanyol pada Masa Daulah Bani Umayyah" Tasyri': Jurnal Tarbiyah-Syari'ah Islamiyah,

25(2). 
http://ejournal.kopertais4.or.id/pantur a/index.php/tasyri/article/view/3324.

Muttaqin, Ahmad Izza \& Riza Faishol. (2018). "Pendampingan Pendidikan Non Formal Diposdaya Masjid Jami' An-Nur Desa Cluring Banyuwangi” 1(1).

http://ejournal.iaiibrahimy.ac.id/inde x.php/Abdi_Kami/article/view/235.

Nasir, Muhammad. (2017). "Sejarah Lembaga Pendidikan Islam (Madrasah) di Indonesia" al-Qalam: Jurnal Ilmiah Keagamaan dan Kemasyarakatan, 11(24).

https://jurnal.stiqamuntai.ac.id/index.php/alqalam/article/view/15.

Nasution, Harun. (1996). Pembaharuan dalam Islam (Sejarah Pemikiran dan Gerakan). Jakarta: Bulan Bintang.

Nasution, Abdul Gani Jamora. (2018). Pendidikan Islam dalam Catatan Sejarah. Yogyakarta: Magnum.

Natsir, Ahmad, et.al. (2020). "Revitalisasi Fungsi Masjid Sebagai Pusat Pengajaran Alquran Melalui Pelatihan Manajemen Madrasah Diniyyah di Dusun Selungguh Kabupaten Magetan" InEJ: Indonesian Engangement Journal, 1(1).

https://jurnal.iainponorogo.ac.id/inde x.php/inej/article/view/2047.

Nizah, Nuriyatun. (2016). "Dinamika Madrasah Diniyah: Suatu Tinjauan Historis" Edukasia: Jurnal Penelitian Pendidikan Islam, 11(1). https://journal.iainkudus.ac.id/index. $\mathrm{php/Edukasia/article/view/810.}$

Nurhayati, Anin. (2013). "Fenomena Madrasah Pasca SKB 3 Menteri Tahun 1975 dan Implikasinya Terhadap Dunia Pendidikan Islam" 1(2): 133-144. https://doi.org/10.21274/taalum.2013 1.2.133-144.

Nurriqi, Afida. (2021). "Karakteristik Pendidikan Agama Islam di Madrasah Perspektif Kebijakan Pendidikan" Bintang: Jurnal
Pendidikan dan Sains, 3(1). https://ejournal.stitpn.ac.id/index.php /bintang/article/view/1152.

Pakpahan, Rustam. (2018). "Konsep Masjid Ramah Anak dalam Pandangan Badan Kemakmuran Masjid (BKM)" Jurnal Penelitian Medan Agama, 9(2). http://jurnal.uinsu.ac.id/index.php/me dag/article/view/3976.

Prastowo, Andi. (2014). Pembelajaran Konstruksivistik-Scientific untuk Pendidikan Agama di Sekolah/Madrasah: Teori, Aplikasi dan Riset Terkait. Jakarta: Rajawali Pers.

Pratama, Yoga Anjas. (2019). "Integrasi Pendidikan Madrasah dalam Sistem Pendidikan Nasional (Studi Kebijakan Pendidikan Madrasah di Indonesia)" Al-Tadzkiyyah: Jurnal Pendidikan Islam, 10(1). https://doi.org/10.24042/atjpi.v10i1.3 $\underline{838}$.

Prayitno. (2010). "Masjid Besar Kota Salatiga" Undergraduate Thesis. Jurusan Arsitektur, Fakultas Teknik Universitas Diponegoro. http://eprints.undip.ac.id/20448/.

Purwaningrum, Septiana. (2021). "Optimalisasi Peran Masjid sebagai Sarana Ibadah dan Pendidikan Islam (Studi Kasus di Masjid Namira Lamongan)" Inovatif, 7(1). http://jurnal.iaih.ac.id/index.php/inov atif/article/view/210.

Putra, Ahmad \& Prasetio Rumondor. (2019). "Eksistensi Masjid di Era Rasulullah dan Era Millenial" Tasamuh, $17(1)$. https://doi.org/10.20414/tasamuh.v17 i1.1218.

Rafiq, M Nafiur. (2017). "Integrasi Ilmu Agama dan Sains dalam Praksis Pendidikan" Falasifa: Jurnal Studi Keislaman, $\quad 8(1)$. http://ejournal.inaifas.ac.id/index.php /falasifa/article/view/43.

Rahim, Abdan. (2014). "Peran Madrasah Sebagai Pendidikan Islam Masa Kini 
(Studi Tradisi dan Perubahan)" AtTa'dib: Journal of Pesantren Education, $9(2)$. https://ejournal.unida.gontor.ac.id/in dex.php/tadib/article/view/312.

Rahman, Fazlur. (2000). Islam. Terj. Ahsin Mohamad. Bandung: Pustaka

Rahmawati, Farida. (2019). "Manajemen Program Sekolah Ramah Anak dalam Meningkatkan Karakter Siswa Madrasah Aliyah" Seminar Nasional Penguatan Karakter Berbasis Literasi Ajaran Tamansiswa Menghadapi Revolusi Industri 4.0, 28 September 2019, 1(1). https://jurnal.ustjogja.ac.id/index.php /semnasmp2019/article/view/5416.

Ramayulis. (2011). Sejarah Pendidikan Islam. Jakarta: Kalam Mulia.

Reezt, Dietrich. (2005). "Dar al-'Ulum Deoband and its Self-Representation on the Media" 44(2): 209-227. https://www.jstor.org/stable/2083896 2 ? seq $=1$.

Rifa'i, Ahmad. (2016). 'Revitalisasi Fungsi Masjid dalam Kehidupan Masyarakat Modern" Universum: Jurnal Keislaman dan Kebudayaan, 10(2).

https://jurnal.iainkediri.ac.id/index.p hp/universum/article/view/256.

Rohana, Syarifah. (2020). "Institusi Pendidikan pada Masa Dinasti Saljuq" Bidayah: Jurnal Studi Ilmuilmu Keislaman, 11(1). http://ejournal.staindirundeng.ac.id/i ndex.php/bidayah/article/view/338.

Rumondor, Prasetio \& Rohit Mahatir Manese. (2020). "Eksistensi Masjid di Perkotaan dalam Pengembangan Pendidikan Agama Islam" Proceeding the First International Conference on Islamic Thought (ICIT) IAI Al Khairat Pamekasan 18 Januari 2020. https://osf.io/s3cjh.

Salim, Ahmad. (2015). "Manajemen Pendidikan Karakter di Madrasah (Sebuah Konsep dan Penerapannya)" Tarbawi: Jurnal Keilmuan Manajemen Pendidikan, 1(2). http://103.20.188.221/index.php/tarb awi/article/view/1999.

Sassi, Komaruddin. (2019). "Pendidikan Islam pada Era Kemunduran Pasca Kejatuhan Baghdad dan Cordova" Taujih: Jurnal Pendidikan Islam, 12(1). $\quad$ http://ejurnal.stitqi.ac.id/index.php/taujih/art icle/view/153.

Shalaby, Ahmad. (1976). Sejarah Pendidikan Islam. Terj. Mukhtar Yahya, dkk. Singapura: Pustaka Nasional.

Sholeh, M. Asrorun Ni'am \& Lutfi Humaidi. (2016). Panduan Sekolah dan Madrasah Ramah Anak. Jakarta: Erlangga.

Silfia, Lina. (2013). "Peran Masjid dalam Meningkatkan Kualitas Pendidikan Islam (Studi Kasus di Masjid AtTaqwa Ngares, Kadireso, Teras, Boyolali)" Skripsi. Universitas Muhammadiyah Surakarta. http://eprints.ums.ac.id/25843/.

Siren, Nor Raudah Hj., et.al. (2014). "Sistem Pendidikan Islam Sekolah Agama (Madrasah) di Singapura" Jurnal of Al-Tamaddun, 9(2). https://jati.um.edu.my/index.php/JAT /article/view/8674.

Styaningsih, Rini. (2016). "Kontinuitas Pesantren dan Madrasah di Indonesia" At-Ta'dib: Journal of Pesantren Education, 11(1). https://ejournal.unida.gontor.ac.id/in dex.php/tadib/article/view/651.

Sudarsono. (2018). "Kebijakan Pendidikan Islam di Madrasah (Pra dan Pasca SKB 3 Menteri Tahun 1975 dan dalam UU Sisdiknas No 20 Tahun 2003)" Widya Balina: Jurnal Ilmu Pendidikan dan Ekonomi, 3(6). http://journal.staidenpasar.ac.id/index .php/wb/article/view/17

Sukma, Wahida, et.al. (2019). "Implementasi Pendidikan Ramah Anak Madrasah di MI Tarbiyatul Ulum Batu Malang" Jurnal Pendidikan Madrasah Ibtidaiyah, 1(3). 
http://www.riset.unisma.ac.id/index. php/JPMI/article/view/3228.

Surajudeen, Ahmad Tijani \& Muhammad Zahiri Awang Mat. (2013). "Classification and Integration of Knowledge: The Qur'anic Educational Model" Revelation and Science, $3(2)$. https://journals.iium.edu.my/revival/i ndex.php/revival/article/view/95.

Susilawati, Samsul. (2008). "Eksistensi Madrasah dalam Pendidikan Indonesia" 1(1). http://ejournal.uinmalang.ac.id/index.php/madrasah/arti cle/view/1852.

Sutarman \& Heru Tjahjono. (2019). "The Effectiveness of Spiritual Quotient and Adversity Quotient Values Education of Madrasah Mu'allimaat Muhammadiyah Yogyakarta Indonesia" Proceedings of the 2019 Ahmad Dahlan International Conference Series on Education \& Learning, Social Science \& Humanities. https://www.atlantispress.com/proceedings/adics-elssh19/125924469.

Syahid. (2018). "Pertumbuhan Madrasah (Periode Awal Hingga Madrasah Nizhamiyah)" Qathruna: Jurnal Keilmuan dan Pendidikan, 5(1). http://www.jurnal.uinbanten.ac.id/ind ex.php/qathruna/article/view/2968.

Syamsul, Huda. (2020). Integrasi Ilmu antara Wacana dan Praktik: Studi Komparatif UIA Malaysia \& UIN Malang. Kediri: Spasi Book.

Syarifuddin, Nur. (2017). "Madrasah Sebagai Bentuk Transformasi Pendidikan Islam di Indonesia" $\mathrm{Al}$ Ibrah: Jurnal Pendidikan dan Kemajuan Islam, 2(2). http://ejournal.stital.ac.id/index.php/a librah/article/view/29.

Tamrin, M. Isnando. (2018). "Pendidikan Non Formal Berbasis Masjid sebagai Bentuk Tanggung Jawab Umat dalam Perspektif Pendidikan Seumur Hidup" Menara Ilmu, 12(1). https://www.jurnal.umsb.ac.id/index. $\mathrm{php} / \mathrm{menarailmu} /$ article/download/48 9/428.

Wage. (2018). "Memfungsikan Masjid Sebagai Tempat Pendidikan Islam" Islamidina: Jurnal Pemikiran Islam, 19(2).

http://www.jurnalnasional.ump.ac.id/ index.php/ISLAMADINA/article/vie $\mathrm{w} / 2476$.

Wardi, Moh., et.al. (2019). "Perbandingan Pendidikan; Pemahaman Simbolis dan Substantif PAI di Madrasah dan PAI di Sekolah Umum" Nidhomul Haq: Jurnal Manajemen Pendidikan Islam, 4(1). $\quad$ https://ejournal.ikhac.ac.id/index.php/nidhom ulhaq/article/view/104.

Wekke, Ismail Suardi, et.al. (2018). "Pasar, Masjid, dan Madrasah: Pendidikan Islam di Minoritas Muslim" Qalam: Jurnal Ilmu Kependidikan, 7(1). https://doi.org/10.33506/jq.v7i1.352.

Zaimuddin. (2018). "Kemunduran Pendidikan Islam" I'tibar: Jurnal Pendidikan Islam Anak Usia Dini, 2(2). $\quad$ http://ejurnal.stitqi.ac.id/index.php/itibar/arti cle/view/144.

Zuhdi, A. (2012). "Madrasah Sebagai Tipologi Lembaga Pendidikan Islam (Kajian tentang Berbagai Model Madrasah Unggulan)" Madrasah: Jurnal Pendidikan dan Pembelajaran Dasar, 5(1). http://ejournal.uinmalang.ac.id/index.php/madrasah/arti cle/view/2230. 